\title{
STRUKTUR KOMUNITAS ECHINODERMATA DI PADANG LAMUN \\ PULAU TANAKEKE KABUPATEN TAKALAR SULAWESI SELATAN
}

\section{COMMUNITY STRUCTURE OF ECHINODERMATA IN SEAGRASS MEADOW OF TANAKEKE ISLAND TAKALAR REGENCY SOUTH SULAWESI}

\author{
Febriyanti Angreni, Magdalena Litaay, Dody Priosambodo, Willem Moka \\ Departemen Biologi, Fakultas Matematika dan IImu Pengetahuan Alam \\ Universitas Hasanuddin, Makassar, 90245 \\ angrenif@gmail.com
}

\begin{abstract}
Abstrak
Penelitian tentang struktur komunitas Echinodermata di padang lamun perairan desa Balangdatu, Pulau Tanakeke kabupaten Takalar Sulawesi Selatan telah dilakukan pada bulan Oktober 2016 - Pebruari 2017. Tujuan penelitian ini adalah untuk mengetahui struktur komunitas Echinodermata di padang lamun pulau Tanakeke. Pengambilan sampel dilakukan dengan metode transek kombinasi plot dengan ukuran plot $2 \times 2$ meter pada tiga stasiun berbeda. Analisis data mencakup penghitungan nilai kepadatan, Indeks keanekaragaman dan Indeks penyebaran. Hasil penelitian menunjukkan terdapat 11 spesies Echinodermata dari 7 suku. Kepadatan jenis tertinggi ditemukan pada Ophiocoma erinaceus yaitu $7,85 \mathrm{ind} / \mathrm{m}^{2}$. Indeks keanekaragaman tergolong rendah menunjukkan kondisi lingkungan yang tertekan. Nilai Indeks penyebaran yang di seluruh stasiun lebih dari satu, menunjukkan bahwa pola penyebaran individu cenderung mengelompok.
\end{abstract}

Kata kunci : struktur komunitas, echinodermata, padang lamun, tanakeke

\begin{abstract}
The research about community structure of Echinodernata has been conducted in seagrass meadow of Balangdatu waters, Tanakeke Island Takalar Regency South Sulawesi from October 2016 to February 2017. The aim of this research was to know the community structure of Echinodermata in seagrass meadow of Tanakeke Island. Sampling activities were set up with transect quadrate method with plot size $2 \times 2$ meter in three different station. Data analysis consist of density, Shannon-Wiener index and Morisita dispersion index. Result showed there were found 11 species of Echinodermata from 7 families. The highest density was found in Ophiocoma erinaceus with density 7,85 ind $/ \mathrm{m}^{2}$. Diversity index was low, showing that environmental condition in pressure. Dispersion index from all station was more than one indicating that the dispersion pattern tend to be clumped.
\end{abstract}

Key words :community structure, echinodermata, seagrass meadow, tanakek 


\section{Pendahuluan}

Salah satu kawasan strategis di Kabupaten Takalar adalah Kepulauan Tanakeke. Tanakeke merupakan Pulau terbesar di Kepulauan Spermonde yang secara geomorfologi berbentuk kepulauan dan terdiri dari beberapa pulau. Wilayah ini dikenal memiliki keanekaragaman hayati yang tinggi. Ekosistem mangrove dan padang lamun yang luas dapat ditemukan di sekitar pulau Tanakeke (Nurdin, 2014).

Echinodermata merupakan salah satu hewan yang sangat penting dalam ekosistem laut dan bermanfaat sebagai salah satu komponen dalam rantai makanan, pemakan sampah organik dan hewan kecil lainnya. Echinodermata dapat bersifat pemakan seston atau pemakan destritus, sehingga peranannya dalam suatu ekosistem untuk merombak sisa-sisa bahan organik yang tidak terpakai oleh spesies lain namun dapat dimanfaatkan oleh beberapa jenis Echinodermata (Hernandez et al., 2006). Beberapa spesies dari kelompok Echinodermata seperti bulu babi dan teripang biasanya dicari oleh masyarakat karena memiliki nilai ekonomi dan protein yang tinggi. Teripang adalah sumber penting bagi industri makanan dan obat-obatan di Malaysia (Jontila et al., 2014). Sementara itu, bulu babi diperdagangkan untuk dimanfaatkan gonadnya (Hammer et al., 2006). Echinodermata juga berperan penting dalam ekosistem padang lamun sebagai konsumen tingkat 1 yang dapat memperkecil kemungkinan terjadi blooming. Secara ekologis penurunan ekosistem lamun berdampak biota dan padang lamun memiliki peranan penting bagi habitat Echinodermata.

Ekosistem lamun sangat penting bagi kehidupan laut. Secara fisik, lamun bertindak sebagai stabilisator sedimen serta melindungi pantai dari erosi. Lamun berfungsi sebagai beragam habitat bagi banyak spesies laut. Padang lamun juga berfungsi sebagai perlindungan dan sumber nutrisi yang mempertahankan rantai makanan yang kompleks (Uneputty et al., 2017).

\section{Alat dan Bahan}

\section{Bahan dan Metode Penelitian}

Alat yang digunakan dalam penelitian ini adalah GPS (Global Positioning System), Handrefraktometer, DO-meter, pH-meter, Thermometer, kantong sampel, pensil dan kertas bawah air, meteran gulung, tali nilon, patok, transek kuadran $2 \times 2$ meter, kamera bawah air, gelas kimia, pipet tetes, nampan, kertas label, tisu gulung, buku identifikasi, kamera, timbangan digital, alat tulis menulis, kertas saring, tabung reaksi, rak tabung, Erlenmeyer, pipet tetes, dan Spektrofotometer DREL 2800,

Bahan yang digunakan antara lain sampel Echinodermata sebagai bahan observasi, tisu gulung, indikator Brucine, asam Sulfat pekat $\left(\mathrm{H}_{2} \mathrm{SO}_{4}\right)$, Natrium Nitrat $\left(\mathrm{NaNO}_{3}\right)$, Ammonium Molybdate $4 \%$, asamBorat $\left(\mathrm{H}_{3} \mathrm{BO}_{3}\right) 1 \%$, asam Sulfat $\left(\mathrm{H}_{2} \mathrm{SO}_{4}\right) 2,5$ $\mathrm{M}$, asam Ascorbic $1 \%$.

\section{Metode Penelitian}

Metode penelitian yang digunakan adalah metode transek kombinasi plot secara sistematis. Pengambilan data dilakukan dengan metode transek kuadrat.

\section{Deskripsi Lokasi Penelitian}

Lokasi penelitian terletak di Desa Balandatu, Kecamatan Mappakasunggu, Kepulauan Tanakeke, Kabupaten Takalar, Sulawesi Selatan. Bentuk Kepulauan Tanakeke tidak secara sporadis terpisah, tetapi cenderung dibatasi oleh perairan didalam gugusan pulau dengan pola melingkar (Brown, 2013). Total luas daratan Kepulauan Tanakeke mencapai $8,37 \mathrm{~km}^{2}$ (Nurdin, 2014). Stasiun pengamatan yang menjadi titik pengambilan sampel terdiri atas tiga stasiun. Stasiun I berlokasi di Dusun Balangloe, terletak dekat dengan 
teluk kecil dan memiliki substrat berpasir dengan pecahan karang dan budidaya rumput laut kurang. Stasiun II berlokasi di Dusun Bungunglompoa, terletak di daerah kegiatan pembudidayaan rumput laut dengan substrat berpasir. Stasiun III berlokasi di Dusun Balandatu Pesisir, terletak dekat dengan pemukiman penduduk, substrat lumpur berpasir.
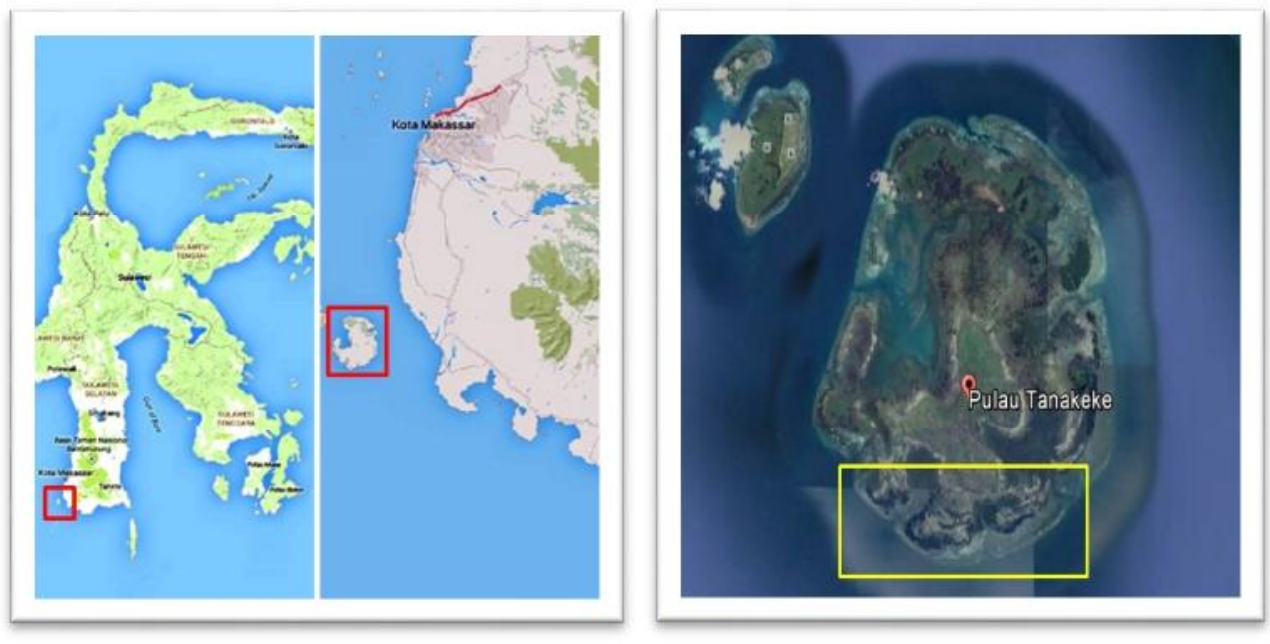

Gambar 1: Peta Pulau Tanakeke, Kabupaten Takalar, Sulawesi Selatan. Sumber: Google earth (2016)

Prosedur Kerja

Pengambilan sampel dilakukan menggunakan 3 (tiga) transek pada setiap stasiun. Jarak antar transek masing-masing $50 \mathrm{~m}$. Pemasangan transek menggunakan pipa paralon berbentuk persegi. Setiap transek dibagi menjadi 5 (lima) titik plot. Plot yang digunakan berukuran $2 \times 2 \mathrm{~m}$ terbuat dari pipa paralon yang membentuk segi empat, jarak antar plot di tentukan sesuai panjang transek.

\section{Identifikasi dan Pengamatan Sampel}

Sampel Echinodermata yang telah diambil dari laut dikumpulkan dalam kantong sampel kemudian diawetkan dengan alkohol $70 \%$. Identifikasi sampel berdasarkan karakteristik morfologi dilakukan berdasarkan referensi yang akan dilakukan di Laboratorium IImu Lingkungan dan Kelautan, Departemen Biologi, Fakultas Matematika dan IImu Pengetahuan Alam, Universitas Hasanuddin, Makassar.

Pengukuran Parameter Oseanografi

Parameter lingkungan yang diukur meliputi lain suhu, salinitas, $\mathrm{pH}$, oksigen terlarut (DO-Dissolved Oxygen) dan $\mathrm{CO}_{2}$ bebas, kekeruhan, nitrat, fosfat dan tekstur sedimen (substrat).

Analisis Data

Analisis data dilakukan dengan perhitungan komponen struktur berupa kepadatan jenis, Indeks Keanekaragaman (Shannon-Wienner) dan Penyebaran species dihitung untuk mengetahui kenakeragaman species Echinodermata dan melihat tingkat pengelompokan dari individu. 


\section{Hasil dan Pembahasan}

\section{Analisis Data}

Hasil penelitian menunjukkan Echinodermata yang teridentifikasi yakni 4 kelas, 5 ordo, 7 suku, dan 11 jenis, yaitu Archaster typicus, Disasterina abnormalis, Protoreaster nodosus, Ophiocoma erinaceus, Diadema setosum, Tripneustes gratilla, Synapta maculata, Holothuria atra, Actinopyga miliaris, Holothuria forskali dan Euapta godeffroyi.

Tabel 1. Komposisi Jenis Echinodermata yang ditemukan di Padang Lamun Perairan Balangdatu, Pulau Tanakeke Kabupaten Takalar

Keterangan:

\begin{tabular}{|c|c|c|c|c|}
\hline \multirow[b]{2}{*}{ No } & \multirow[b]{2}{*}{ Jenis Echinodermata } & \multicolumn{3}{|c|}{ STASIUN } \\
\hline & & $\mathrm{I}$ & II & III \\
\hline & ASTEROIDEA & & & \\
\hline 1 & Archaster typicus & + & + & - \\
\hline 2 & $\begin{array}{l}\text { Disasterina } \\
\text { abnormalis }\end{array}$ & + & - & - \\
\hline 3 & Protoreaster nodosus & - & + & + \\
\hline & OPHIUROIDEA & & & \\
\hline 4 & Ophiocoma erinaceus & + & - & - \\
\hline & ECHINOIDEA & & & \\
\hline 5 & Diadema setosum & - & - & + \\
\hline 6 & Tripneustes gratilla & - & - & + \\
\hline & HOLOTHUROIDEA & & & \\
\hline 7 & Synapta maculata & + & - & + \\
\hline 8 & Holothuria atra & + & - & - \\
\hline 9 & Actinopyga miliaris & + & - & - \\
\hline 10 & Holothuria forskali & + & - & - \\
\hline 11 & Euapta godeffroyi & - & + & - \\
\hline
\end{tabular}

$$
\text { - : Tidak Ada }
$$

Kepadatan (D)

Hasil analisis data sampling Echinodermata menunjukkan kepadatan Echinodermata di stasiun I adalah 7,99 individu/ $\mathrm{m}^{2}$ dan di stasiun II 0,23 individu $/ \mathrm{m}^{2}$ sedangkan pada stasiun III $0,86 \mathrm{ind} / \mathrm{m}^{2}$. Kepadatan tertinggi ditemukan pada jenis Ophiocoma erinaceus dan terendah adalah jenis Tripneustes gratilla, Holothuria atra, dan Actinopyga miliaris dengan nilai ratarata 0,01 individu $/ \mathrm{m}^{2}$ (Tabel 2). Ophiocoma erinaceus merupakan jenis Echinodermata dari familia Ophiomidae yang paling mendominasi di stasiun I dengan nilai kepadatan yaitu $7,85 \mathrm{ind} / \mathrm{m}^{2}$. Jenis Ophiocoma erinaceus ditemukan di padang lamun stasiun I.

Lambert (2010) menyatakan bahwa Holothuria atra mempunyai mekanisme pertahanan diri yang tinggi, dimana Holothuria atra menempeli tubuhnya dengan butiran-butiran pasir. Pasir yang menempel pada tubuh Holothuria. atra memantulkan cahaya dan membuat suhu tubuhnya lebih rendah. 
Tabel 2. Nilai Kepadatan (D) di Padang Lamun Perairan Balangdatu, Pulau Tanakeke Kabupaten Takalar

\begin{tabular}{|c|c|c|c|c|}
\hline \multirow[t]{2}{*}{ No } & \multirow[t]{2}{*}{$\begin{array}{c}\text { Jenis } \\
\text { Echinodermata }\end{array}$} & \multicolumn{3}{|c|}{$\begin{array}{l}\text { Kepadatan } \\
\text { (ind } / \mathrm{m}^{2} \text { ) }\end{array}$} \\
\hline & & ST1 & ST2 & ST3 \\
\hline 1 & Archaster typicus & 0,03 & 0,15 & 0 \\
\hline 2 & $\begin{array}{l}\text { Disasterina } \\
\text { abnormalis }\end{array}$ & 0,03 & 0 & 0 \\
\hline 3 & $\begin{array}{c}\text { Protoreaster } \\
\text { nodosus }\end{array}$ & 0 & 0,05 & 0,18 \\
\hline 4 & $\begin{array}{l}\text { Ophiocoma } \\
\text { erinaceus }\end{array}$ & 7,85 & 0 & 0 \\
\hline 5 & Diadema setosum & 0 & 0 & 0,65 \\
\hline 6 & Tripneustes gratilla & 0 & 0 & 0,01 \\
\hline 7 & Synapta maculata & 0,01 & 0 & 0,2 \\
\hline 8 & Holothuria atra & 0,01 & 0 & 0 \\
\hline 9 & Actinopyga miliaris & 0,01 & 0 & 0 \\
\hline 10 & Holothuria forskali & 0,05 & 0 & 0 \\
\hline 11 & Euapta godeffroyi & 0 & 0,03 & 0 \\
\hline & Total & 7,99 & 0,23 & 0,86 \\
\hline
\end{tabular}

Indeks Keanekaragaman ( $\left.\mathrm{H}^{\prime}\right)$

Berdasarkan hasil pengolahan data, diketahui bahwa keanekaragaman jenis Echinodermata pada masing-masing stasiun berkisar antara 0,200 - 0,957 (Tabel 3).

Tabel 3. Nilai Indeks Keanekaragaman Jenis $\left(\mathrm{H}^{\prime}\right)$ di Padang Lamun Perairan Balangdatu, Pulau Tanakeke Kabupaten Takalar

\begin{tabular}{|c|c|c|c|}
\hline No & Stasiun Penelitian & Nilai Indeks & Kategori \\
\hline 1 & I & 0.433 & Rendah \\
\hline 2 & II & 0.200 & Rendah \\
\hline 3 & III & 0.957 & Rendah \\
\hline
\end{tabular}

Indeks keragaman mengukur kelimpahan komunitas berdasarkan jumlah jenis dan jumlah individu dari setiap jenis pada suatu lokasi. Semakin banyak jumlah jenis maka akan semakin beragam komunitasnya. Dengan demikian, keanekaragaman jenis Echinodermata pada stasiun I sampai dengan stasiun III tergolong rendah.

Menurut Karuniasari (2013), keanekaragaman jenis dipengaruhi oleh pembagian atau penyebaran individu dari tiap jenisnya, karena suatu komunitas walaupun banyak jenis tetapi bila penyebaran individunya tidak merata maka keanekaragaman jenisnya rendah. Hal ini menyebabkan kestabilan dalam komunitas yang terjadi berada pada kondisi kurang normal. Selain beberapa parameter lingkungan yang diukur, keanekaragaman Echinodermata juga juga dipengaruhi oleh musim. 
Penyebaran Spesies (Id)

Tabel 4. Nilai Penyebaran Spesies (Id) di Padang Lamun Perairan Balangdatu, Pulau Tanakeke Kabupaten Takalar

\begin{tabular}{|c|c|c|c|}
\hline No & Stasiun Penelitian & Nilai Indeks & Kategori \\
\hline 1 & I & 2,097 & Mengelompok \\
\hline 2 & II & 1,444 & Mengelompok \\
\hline 3 & III & 1,429 & Mengelompok \\
\hline
\end{tabular}

Secara umum pola penyebaran Echinodermata di seluruh stasiun penelitian adalah semua mengelompok. Pola penyebaran mengelompok ditandai dengan indeks Morisita mutlak lebih dari nol. Berdasarkan hasil analisis data pola penyebaran pada setiap stasiun penelitian berkisar antara 1,429 - 2,097 (Tabel 4), menunjukkan bahwa jenis Echinodermata pada stasiun penelitian pola sebarannya adalah mengelompok.

\section{Parameter Lingkungan}

Suhu

Hasil pengukuran suhu pada masing-masing stasiun penelitian menunjukkan kisaran masing-masing stasiun I yaitu $28^{\circ} \mathrm{C}$, stasiun II yaitu $29^{\circ} \mathrm{C}$ dan stasiun III yaitu $33^{\circ} \mathrm{C}$ (Tabel 5 ). Hasil Kisaran ini merupakan suhu yang cukup tinggi, hal ini disebabkan karena pada saat sampling Echinodermata dilakukan dalam kondisi surut rendah pada siang hari. Temperatur normal kehidupan organisme di air laut adalah sekitar $26-32^{\circ} \mathrm{C}$, tetapi jenis avertebrata dapat mentolerir suhu yang lebih tinggi. Dengan demikian suhu yang diukur pada masing-masing stasiun masih berada dalam kondisi normal dan mendukung kehidupan Echinodermata.

\section{Derajat Keasaman $(\mathrm{pH})$}

Hasil pengukuran parameter lingkungan pada masing-masing stasiun penelitian menunjukkan kisaran $\mathrm{pH}$ antara 8,4 sampai 8,6 (Tabel 5). Umumnya $\mathrm{pH}$ air laut sedikit basa, antara 7,5 - 8,4. Nilai pH ideal bagi kehidupan organisme air pada umumnya yaitu antara $7-8,5$. $\mathrm{pH}$ yang diukur pada masing-masing stasiun masih dalam kondisi normal untuk mendukung kehidupan Echinodermata.

\section{Salinitas}

Hasil pengukuran dan analisis sampel air di perairan dusun Balangdatu diperoleh kisaran salinitas antara $28 \%-28,6 \%$ (Tabel 5). Hasil penelitian ini tidak berbeda jauh dengan penelitian yang dilakukan oleh Toha (2012), bahwa salinitas habitat Echinodermata berkisar antara $30 \%-31 \%$. Kisaran salinitas yang diukur pada setiap stasiun masih tergolong normal, karena masih mendukung kehidupan organisme perairan khususnya fauna makrobentos termasuk Echinodermata adalah 15-35 ppt.

Oksigen Terlarut (DO)

Hasil pengukuran di perairan dusun Balangdatu yaitu berkisar antara 7,73 mg/l $7,8 \mathrm{mg} / \mathrm{l}$. Baku mutu oksigen terlarut suatu perairan adalah $>4 \mathrm{mg} / \mathrm{l}$. Hasil ini 
berbeda dengan temuan Edward (2004) yang menemukan kisaran oksigen terlarut antara 2,6-4,6 mg/l pada kedalaman 0-50 m. Penelitian ini sesuai pada penelitian yang dilakukan oleh (Arifin, 2011) yang menyatakan bahwa kandungan oksigen terlarut di perairan pesisir Makassar berkisar antara 4,853 mg/l - 8,587 $\mathrm{mg} / \mathrm{l}$ dengan rata-rata $6,474 \mathrm{mg} / \mathrm{l}$, dan untuk zona dekat pantai berkisar antara $4,853 \mathrm{mg} / \mathrm{l}-6,817 \mathrm{mg} / \mathrm{l}$ dengan rata-rata 5,481 mg/l (Tabel 5). Berdasarkan hal ini, kandungan oksigen terlarut yang diukur pada setiap stasiun penelitian masih tergolong normal untuk mendukung kehidupan biota laur khususnya Echinodermata.

Nitrat $\left(\mathrm{NO}_{3}\right)$ dan Fosfat $\left(\mathrm{PO}_{4}\right)$

Hasil pengukuran yang telah dilakukan dilapangan menunjukkan angka antara 0,242 - 0,278 Secara umum kandungan nitrat di perairan Balangdatu masih sesuai dengan kandungan nitrat yang umum dijumpai di perairan laut. Kandungan nitrat yang normal di perairan laut umumnya berkisar antara 0,01 $50 \mathrm{mg} / \mathrm{l}$ (lqodry et al. 2010).

Kandungan fosfat pada perairan Balangdatu di stasiun I sampai dengan stasiun III menunjukkan angka 0,02 sampai 0,05 (Tabel 5). Kandungan ini masih sesuai dengan kandungan fosfat yang umumnya dijumpai di perairan laut.

\section{Kekeruhan}

Kekeruhan air yang tercatat dan diukur pada setiap stasiun penelitian, hasilnya bervariasi dan berkisar antara 0,88 - 4,50 NTU (Tabel 5). Hasil pengukuran tersebut sesuai dengan Standar Baku Mutu air laut yang mencatat bahwa nilai kekeruhan yang sesuai untuk kehidupan biota laut adalah $<5$ NTU. Hasil pengukuran kekeruhan setiap stasiun penelitian, masih tergolong normal untuk mendukung kehidupan Echinodermata.

\section{$\mathrm{CO}_{2}$ Bebas}

Kadar karbondioksida $5 \mathrm{mg} / \mathrm{l}$ di dalam air masih dapat ditoleransi oleh hewan air. Kandungan oksigen terlarut dalam tambak selama penelitian yaitu antara 2,13 sampai 5,99 mg/l (Tabel 5) masih tergolong konsentrasi yang baik untuk pertumbuhan Echinodermata. Biota perairan masih dapat mentolerir karbondioksida bebas yaitu antara 5-7 mg/l (Kordi dan Tancung, 2007).

\section{Karakteristik Substrat}

Komunitas makrozoobentos (jumlah jenis, kepadatan dan keanekaragaman) antar daerah dipengaruhi langsung oleh tipe substrat (Gholizadeh et al., 2012). Hasil analisis tekstur sedimen menggunakan metode pipet menunjukkan jenis sedimen pada semua stasiun penelitian di padang lamun Desa Balangdatu tergolong bertekstur lempung berpasir (Tabel 6). Dengan berbagai komposisi tekstur sedimen yang berbeda-beda dari setiap stasiun yaitu struktur pasir berkisar antara 55\% - 62\%, pasir halus berkisar antara $17 \%-19 \%$, debu berkisar antara 7\% - 11\%, dan tekstur liat berkisar antara 11\% - 18\%. Resuspensi sedimen adalah salah satu proses yang berpotensi memberikan kontribusi masukan nutrien seperti nitrat dan fosfat yang berasal dari sedimen ke kolom air (Dzialowski et al., (2008). Selanjutnya dijelaskan oleh Zhang et al (2014), bahwa sedimen merupakan tempat penyimpanan dan pelepas material ke kolom air di perairan muara dan pantai. Senyawa fosfor yang terikat di sedimen mengalami dekomposisi dengan bantuan bakteri melalui proses abiotik 
menghasilkan senyawa fosfat terlarut dapat mengalami difusi kembali ke dalam kolom air.

Tabel 5. Nilai Parameter Lingkungan di Padang Lamun Perairan Balangdatu, Pulau Tanakeke Kabupaten Takalar

\begin{tabular}{|c|c|c|c|}
\hline \multirow{2}{*}{$\begin{array}{l}\text { Parameter } \\
\text { Lingkungan }\end{array}$} & \multicolumn{3}{|c|}{ Stasiun Penelitian } \\
\hline & I & II & III \\
\hline Suhu $\left({ }^{\circ}\right)$ & 28 & 29 & 33 \\
\hline $\mathrm{pH}$ & 8,4 & 8,4 & 8,6 \\
\hline $\begin{array}{c}\text { Salinitas } \\
(\%)\end{array}$ & 28 & 27 & 28,6 \\
\hline Do $(\mathrm{mg} / \mathrm{l})$ & 7,8 & 7,73 & 7,53 \\
\hline $\begin{array}{c}\text { Nitrat/ } / \mathrm{NO}_{3}( \\
\mathrm{mg} / \mathrm{l})\end{array}$ & 0,278 & 0,242 & 0,264 \\
\hline $\begin{array}{c}\text { Fosfat/PO } \mathrm{P}_{4}( \\
\mathrm{mg} / \mathrm{l})\end{array}$ & 0,002 & 0,001 & 0,005 \\
\hline $\begin{array}{l}\text { Kekeruhan } \\
\text { (NTU) }\end{array}$ & 0,88 & 1,63 & 4,50 \\
\hline $\begin{array}{c}\mathrm{CO}_{2} \text { Bebas } \\
(\mathrm{mg} / \mathrm{l})\end{array}$ & 5,99 & 5,46 & 2,13 \\
\hline $\begin{array}{c}\text { Karakteristik } \\
\text { Substrat }\end{array}$ & $\begin{array}{c}\text { Lempu } \\
\text { ng } \\
\text { Berpasi } \\
r\end{array}$ & $\begin{array}{l}\text { Lempun } \\
\text { g } \\
\text { Berpasir }\end{array}$ & $\begin{array}{l}\text { Lempung } \\
\text { Berpasir }\end{array}$ \\
\hline
\end{tabular}

Tabel 6. Karakteristik Sedimen di Padang Lamun Perairan Balangdatu, Pulau Tanakeke Kabupaten Takalar

\begin{tabular}{|c|c|c|c|c|c|c|}
\hline \multirow{2}{*}{$\begin{array}{c}\text { N } \\
0\end{array}$} & Kode Contoh & $\begin{array}{c}\text { Pasir } \\
(\%)\end{array}$ & $\begin{array}{c}\text { Pasir Halus } \\
(\%)\end{array}$ & $\begin{array}{c}\text { Debu } \\
(\%)\end{array}$ & Liat (\%) & Tekstur \\
\hline 1 & ST 1 TR 1 & 55 & 17 & 10 & 18 & $\begin{array}{c}\text { Lempung } \\
\text { Berpasir }\end{array}$ \\
\hline 2 & ST 1 TR 2 & 58 & 17 & 9 & 16 & $\begin{array}{c}\text { Lempung } \\
\text { Berpasir }\end{array}$ \\
\hline 3 & ST 1 TR 3 & 62 & 18 & 7 & 13 & $\begin{array}{c}\text { Lempung } \\
\text { Berpasir }\end{array}$ \\
\hline 4 & ST 2 TR 1 & 60 & 19 & 8 & 13 & $\begin{array}{c}\text { Lempung } \\
\text { Berpasir }\end{array}$ \\
\hline 5 & ST 2 TR 2 & 63 & 19 & 6 & 12 & $\begin{array}{c}\text { Lempung } \\
\text { Berpasir }\end{array}$ \\
\hline 6 & ST 2 TR 3 & 60 & 18 & 8 & 14 & $\begin{array}{c}\text { Lempung } \\
\text { Berpasir }\end{array}$ \\
\hline 7 & ST 3 TR 1 & 62 & 19 & 8 & 11 & $\begin{array}{c}\text { Lempung } \\
\text { Berpasir }\end{array}$ \\
\hline 8 & ST 3 TR 2 & 58 & 18 & 8 & 16 & $\begin{array}{c}\text { Lempung } \\
\text { Berpasir }\end{array}$ \\
\hline 9 & ST 3 TR 3 & 55 & 17 & 11 & 17 & $\begin{array}{c}\text { Lempung } \\
\text { Berpasir }\end{array}$ \\
\hline
\end{tabular}

$$
\begin{array}{ll}
\text { Keterangan : } & \text { ST }=\text { Stasiun } \\
& \text { TR }=\text { Transek }
\end{array}
$$




\section{Kesimpulan}

Hasil penelitian di perairan Desa Balangdatu Pulau Tanakeke terdapat 11 jenis Echinodermata dari 7 Familia. Kepadatan tertinggi adalah Ophiocoma erinaceus dengan nilai kepadatan $7,85 \mathrm{ind} / \mathrm{m}^{2}$ dan terendah adalah jenis Tripneustes gratilla, Holothuria atra, dan Actinopyga miliaris dengan nilai rata-rata 0,01 ind $/ \mathrm{m}^{2}$. Secara umum keanekaragaman jenis Echinodermata dikategorikan rendah dengan penyebaran cenderung mengelompok, yang menunjukkan lingkungan kurang stabil.

\section{Ucapan Terima Kasih}

Penulis mengucapkan terima kasih kepada direktur Yayasan Hutan Biru Indonesia Muhammad Yusran dan tim penelitinya: Rizpah Hamzah, Muh. Akhzan, Muh. Ikhsan dan Muh.Sadik serta masyarakat Balangdatu Pulau Tanakeke.

\section{Daftar Pustaka}

Arifin. T., Yulius dan I. S. Arliya. 2011. Pola Sebaran Spasial Karagteristik NitratFosfat-Oksigen Terlarut di Perairan Pesisir Makassar. Jurnal Segara. 7(2): 88-96.

Brown, B. M., 2013. Mangrove Management Challenges on Tanakeke Island. Mangrove Journal. Restoring Coaastal Livelihoods. CIDA, OXFAM-GB, MAP-Indonesia. South Sulawesi.

Dzialowski, A.R. W. Dzialowski, L. Shih-Hsien., J.H. Niang-Choo., Beury and D.G. Huggins. 2008. Effects of Sediment Resuspension on Nutrient Consentrations and Algal Biomass in Reservoir of the Central Plains. Lake Reservoir Manag. 24:313-320.

Edwards, M., and A.J. Richardson. 2004. Impact of climate change on marine pelagic phenology and trophic mismatch. Nature. 430, 881-884.

Gholizadeh, M., A. Yahya. O. Talib. 2012. Effects of environmental factors on polychaete assemblage in Penang National Park, Malaysia. Word Academy of Science, Engineering and Technology Journal. 72: 669-672.

Hammer H, W.S. Lawrence. 2006. The effect of dietary protein and carbohydrate concentration on the biochemical composition and gametogenic condition of the sea urchin Lytechinus variegatus. Journal of Experimental Marine Biology and Ecology. 334:109-121

Iqodry, T.Z., Yulisman., M Syahdan dan Santoso. 2010. Karakterisitik dan sebaran nitrat, fosfat, dan oksigen terlarut di perairan Karimunjawa Jawa Tengah.. Jurnal Penelitian Sains. 13(1)(D) 13109-35 - 13109-41. 
Jontila JBS., R.A.T. Balisco., J.A. Matillano. 2014. The Sea cucumbers (Holothuroidea) of Palawan, Philippines. AACL Bioflux. 7(3):194-206.

Karuniasari, A. 2013. Struktur Komunitas Makrozoobentos sebagai Bioindikator Kualitas Perairan Pulau Panggang Kepulauan Seribu DKI Jakarta. FPIK, Universitas Padjadjaran, Jatinangor.

Kordi, K dan A. B. Tancung. 2007. Pengelolaan Kualitas Air dalam Budidaya Perairan. PT. Rhineka Cipta. Jakarta.

Lambert, P. 2010. Sea cucumbers of British Columbia, Southeast Alaska and Puget Sound. British Columbia. UBC Press.

Nurdin, Y. 2014. Strategi Perkembangan Program Pengelolaan Mangrove Kepulauan Tanakeke. Yayasan Hutan Biru Indonesia. Makassar.

Toha, Abdul Hamid. 2012. Kondisi Habitat Bulu Babi Tripneustes gratilla (Linneaus, 1758) di Teluk Cendrawasih. Jurusan Perikanan, Fakultas Peternakan, Perikanan dan IImu Kelautan, Universitas Negeri Papua, Manokwari, Papua Barat.

Uneputty P.A., M.A Tuapattinaja, JA Pattikawa. 2017. Density and diversity of echinoderms in seagrass bed, Baguala Bay, Maluku, Eastern Indonesia. International Journal of Fisheries and Aquatic Studies. 5(2): 311-315

Zhang, L., K. Lu Wang., Yin., Y. Ying Lu., Yang, and X. Huang. 2014. Spatial and Seasonal Variations of Nutrients in Sediment Profiles and Their SedimentWater Fluxes in the Pearl River Estuary, Southern China. Journal of Earth Science. 25(1) : 197-206. 